\title{
JNPH
}

Volume 5 No. 1 (Juli 2017)

(C) The Author(s) 2017

\section{GAMBARAN KADAR ENZIM CHOLINESTERASE PADA WANITA USIA SUBUR (WUS) YANG AKTIF MEMBANTU AKTIVITAS PERTANIAN DI KECAMATAN SUKARAJA KABUPATEN SELUMA TAHUN 2017}

\author{
DESCRIPTION OF ENZIM CHOLINESTERASE IN ELIGIBLE WOMEN WITH \\ ACTIVE HELPING OF AGRICULTURE ACTIVITIES IN SUKARAJA DISTRICT OF \\ SELUMA REGENCY 2017
}

\author{
BERLIAN KANDO, JON FARIZAL, SUSIWATI \\ POLTEKES KEMENKES BENGKULU \\ SEKOLAH TINGGI ILMU KESEHATAN DEHASEN BENGKULU
}

\begin{abstract}
ABSTRAK
Latar Belakang : Wanita Usia Subur (WUS) yang tinggal di daerah pertanian merupakan salah satu populasi yang beresiko untuk terpapar pestisida dengan dampak negatif jangka panjang. Paparan pestisida dapat menyebabkan penurunan aktivitas enzim Cholinesterase didalam plasma darah dan sel darah merah yang berperan dalam menjaga keseimbangan sistem saraf dengan nilai normal 3990-10800 U/L. Tujuan Penelitian : Penelitian ini bertujuan untuk mengetahui gambaran kadar enzim Cholinesterase pada Wanita Usia Subur (WUS) yang aktif membantu aktifitas pertanian di Kecamatan Sukaraja Kabupaten Seluma tahun 2017. Metode : Penelitian ini menggunakan jenis penelitian deskriptif dengan pendekatan laboratorium yang bertujuan untuk mendapatkan gambaran mengenai ada atau tidaknya penurunan kadar cholinesterase. Sampel pada penelitian ini sebanyak 32 responden sesuai kriteria dengan menggunakan metode total sampling. Pengukuran sampel menggunakan prinsip pembacaan absorban menggunakan spektrofotometer. Hasil : Hasil penelitian menunjukan bahwa sebagian besar responden wanita usia subur $(87,5 \%)$ mengalami penurunan kadar enzim Cholinesterase dan sebagian kecil responden wanita usia subur (12.5\%) memiliki kadar enzim cholinesterase normal. Kesimpulan : Wanita usia subur yang ikut membantu aktivitas pertanian memiliki resiko penurunan kadar enzim cholinesterase. Saran : Upaya yang perlu dilakukan adalah selalu berhati-hati terhadap paparan pestisida. Perlu dilakukan sosialisasi untuk meningkatkan kesehatan masyarakat dalam melakukan aktivitas pertanian serta mencari solusi pengganti pestisida.
\end{abstract}

Kata Kunci : WUS, pestisida, kadar cholinesterase

\begin{abstract}
Background: Women of Fertile Age (WUS) living in agricultural areas are among the populations at risk for exposure to pesticides with long-term negative impacts. Exposure to pesticides can lead to a decrease in the activity of Cholinesterase enzymes in blood plasma and red blood cells that play a role in maintaining a normal nervous system balance of 3990-10800 U / L..Research Objectives: This study aims to determine the description of Cholinesterase enzyme levels in women of fertile age (WUS) who actively assist agricultural activities in SubDistrict Sukaraja Seluma Regency 2017. Method: This study used descriptive research type
\end{abstract}


with laboratory approach which aimed to get an idea about the presence or absence of decreased cholinesterase level. The sample in this study as many as 32 respondents according to criteria by using the total sampling method. The sample measurements use the absorbance reading principle using a spectrophotometer. Results: The results showed that most female respondents of fertile age $(87.5 \%)$ experienced a decrease in Cholinesterase enzyme levels and a small proportion of women of fertile age $(12.5 \%)$ had normal cholinesterase enzyme levels. Conclusion: Women of childbearing age who participate in agricultural activity have a risk of decreased levels of cholinesterase enzyme.

Suggestions: Efforts that need to be done is always cautious of exposure to pesticides. Need to be socialized to improve public health in conducting agricultural activities and seek solutions for replacement pesticides.

\section{Keywords: WUS, pesticide, cholinesterase levels}

\section{PENDAHULUAN}

Wanita usia subur yang tinggal di daerah pertanian merupakan salah satu populasi yang beresiko untuk mengalami keracunan pestisida dengan dampak negatif jangka panjang. Efek negatif dari pajanan pestisida pada kelompok wanita usia subur dapat menimbulkan gangguan kesehatan reproduksi. Hal ini berkaitan dengan keterlibatan dalam aktivitas di bidang pertanian, seperti menyemprot, menyiapkan perlengkapan untuk menyemprot, termasuk mencampur pestisida, mencuci peralatan/pakaian yang dipakai untuk menyemprot, membuang rumput tanaman, mencari hama, menyiram tanaman dan memanen (Purba, 2010).

Pestisida sangat berperan di sektor pertanian dalam memberantas hama dan gulma yang dapat menyebabkan penurunan hasil produksi pertanian. Namun pemakaian pestisida dalam kurun waktu yang cukup lama ibarat tombak bermata dua, disatu sisi pestisida mampu meningkatkan kesejahteraan manusia, akan tetapi disisi lain pestisida membahayakan kesehatan diri petani, konsumen, organisme non target serta lingkungan (Yuntari, Widianarko and Henna Rya Sunoko, 2015). Dampak paparan pestisida dalam jangka waktu yang lama dapat menyebabkan gangguan kesehatan seperti kanker pankreas, kanker prostat, kanker rahim, abrotus spontan, serta gangguan fungsi hati (Ntow et al., 2009).

Paparan yang disebabkan oleh pestisida bertindak sebagai Asetil Cholinesterase (AChE) yang akan menurunkan aktivitas enzim Cholinesterase dalam darah. Aktivitas cholinesterase darah adalah jumlah enzim cholinesterase aktif di dalam plasma darah dan sel darah merah yang berperan dalammenjaga keseimbangan sistem saraf. Aktivitas cholinesterase darah ini dapatdigunakan sebagai indikator keracunan pestisida golongan organofosfat (Ntow et al., 2009).

Colinesterase adalah suatu bentuk enzim dari katalis biologik di dalam jaringan tubuh yang berperan untuk menjaga agar otot-otot, kelenjar-kelenjar dan saraf berkerja secara terorganisir dan harmonis. Jika aktivitas kolinesterase jaringan tubuh menurun secara tepat sampai tingkat rendah, akan berdampak pada bergeraknya serat-serat otot secara sadar dengan gerakan halus maupun kasar, petani dapat mengelurkan air mata akibat mata yang iritasi, serta gerakan otot akan lebih lambat dan lemah. Colinesterase disintesis pada hati (liver) terdapat dalam sinaps, dalam plasma darah merah, yang berfungsi menghentikan implus syaraf dengan cara memecah neurohormon acetylcholinesterase pada sinaps menjadi acetil dan choline (Zuraida, 2012).

\section{METODE PENELITIAN}

Desain penelitian ini merupakan jenis penelitian deskriptif dengan pendekatan laboratorium yang bertujuan untuk mendapatkan gambaran mengenai ada atau 
tidaknya penurunan kadar enzim cholinesterase pada wanita usia subur (WUS) yang berperan aktif membantu aktivitas pertanian di Desa Sidosari Dusun Swadaya Kecamatan Sukaraja Kabupaten Seluma.

Peneliti dalam penelitian melakukan pengukuran kadar enzim cholinesterase (CHE) dilakukan menggunakan metode kinetik yang ditandai adanya reaksi potasium ferosianida menjadi potasium ferisianida yang disebabkan oleh reaksi reduksi yang terjadi dan dilakukan pembacaan hasil menggunakan prinsip pembacaan absorban pada spektrofotometer pada $\lambda 405 \mathrm{~nm}$.

Sampel dalam penelitian ini adalah seluruhWanita Usia Subur (WUS) yang aktif membantu aktivitas pertanian dalam kelompok wanita tani anggrek yang ada di Desa Sidosari Dusun Swadaya pada tahun 2016 dengan total sampel sebanyak 32 orang responden dengan kriteria inklusi aktif membantu aktivitas pertanian yang berhubungan pestisida minimal 2 kali dalam 1 bulan.

\section{HASIL PENELITIAN}

Analisis ini digunakan untuk mendapatkan distribusi frekuensi kadar Enzim Cholinesterase pada Wanita Usia Subur terpapar pestisida di Kecamatan Sukaraja Kabupaten Seluma Tahun 2016, hasil dapat dilihat pada tabel 1 berikut ini:

Tabel 1 Distribusi frekuensi kadar enzim Cholinesterase pada Wanita Usia Subur (WUS) yang aktif membantu aktivitas pertanian

\begin{tabular}{ccc}
\hline Kadar Enzim & Frekuensi & Percentase (\%) \\
\hline Abnormal & 28 & 87.5 \\
\hline Normal & 4 & 12.5 \\
\hline Total & 32 & 100 \\
\hline
\end{tabular}

Dari tabel 1 terlihat hampir seluruh responden wanita usia subur $(87.5 \%)$ dengan kadar enzim cholinesterase abnormal dan sebagian kecil responden (12.5\%) yang memiliki kadar enzim normal.

\section{PEMBAHASAN}

Hasil penelitian dengan total responden berjumlah 32 WUS terlihat bahwa sebanyak 28 orang $(87,5 \%)$ WUS memiliki kadar cholinesterase abnormal (1165-3769 U/L) dan 4 orang WUS (12.5\%) dengan kadar enzim cholinesterase normal. Pada hasil peneliti menemukan bahwa WUS yang mengalami kadar enzim cholinesterase abnormal adalah WUS yang telah lama membantu ikut serta dalam aktivitas pertanian dan ikut serta dalam penyemprotan \pm 1 minggu dari jarak peneliti melakukan sampling, sedangkan untuk WUS yang kadar enzim cholinesterase normal adalah WUS yang belum lama dan jarang ikut serta dalam aktivitas pertanian.

Hasil penelitian diatas dapat dilihat bahwa penurunan kadar enzim cholinesterase disebabkan terpapar pestisida, hal ini berhubungan dengan teori dari William $\mathrm{J}$ Ntow yang mengatakan bahwa paparan yang disebabkan oleh pestisida bertindak sebagai Asetil Cholinesterase (AChE) yang akan menurunkan aktivitas enzim Cholinesterase dalam darah. Aktivitas cholinesterase darah adalah jumlah enzim cholinesterase aktif di dalam plasma darah dan sel darah merah yang berperan dalammenjaga keseimbangan sistem saraf. Aktivitas cholinesterase darah ini dapatdigunakan sebagai indikator keracunan pestisida golongan organofosfat (Ntow et al., 2009).

Penelitian ini sejalan dengan penelitian yang dilakukan oleh Imelda Gernauli Purba pada tahun 2010 dengan judul "Analisis faktor-faktor yang berhubungan dengan kadar Colinesterase pada perempuan usia subur di daerah pertanian" dengan hasil penelitian menunjukkan dari 70 wanita usia subur yang diteliti terdapat $35(50 \%)$ wanita usia subur yang mengalami penurunan aktivitas enzim cholinesterase dalam darah (Purba, 2010).

Pestisida masuk kedalam tubuh manusia dapat secara sedikit demi sedikit dan mengakibatkan keracunan akut yang akan mengakibatkan kematian. Pada penderita keracunan kronis biasanya tidak 
memperdulikan gejala keracunan di tubuhnya beberapa jam setelah menyiapkan dan menggunakan pestisida juga bagi mereka yang berada disekitar tempat pembuatan, pengemasan dan penggunaan pestisida (Ishii and Kurachi, 2006).

Hal ini sejalan dengan penelitian yang dilakukan oleh Rustia dkk pada tahun 2010 dengan judul "Lama Pajanan Organofosfat Terhadap Penurunan Aktivitas Enzim Kolinesterase Dalam Darah Petani Sayuran“ dengan hasil penelitian menunjukan seluruh responden yang berjumlah 56 orang mengalami penurunan aktivitas enzim cholinesterase (Rustia et al., 2010).

Menurut (Asror, Sulistiyani and Hanani, 2008) hasil pemeriksaan aktivitas cholinesterase dapat digunakan sebagai penegas (konfirmasi) terjadinya keracunan pestisida pada seseorang. Sehingga dengan demikian dapat dinyatakan pula bahwa faktor-faktor yang mempengaruhi terjadinya keracunan juga merupakan faktor-faktor yang menyebabkan rendahnya aktivitas cholinesterase darah. Faktor yang berpengaruh terhadap kejadian keracunan pestisida adalah faktor dalam tubuh (internal) dan faktor dari luar tubuh (eksternal).

Cholinesterase adalah enzim darah yang diperlukan agar syaraf dapat berfungsi dengan baik. Ketika seseorang keracunan organofosfat, tingkat aktivitas cholinesterase akan turun. Ada dua tipe cholinesterase dalam darah, yaitu yang terdapat dalam sel darah merah dan yang terdapat dalam plasma darah. Apabila cholinesterase terikat, enzim tidak dapat menjalankan tugasnya dalam tubuh terutama meneruskan perintah ke otot-otot tertentu dalam tubuh, sehingga otot-otot senantiasa bergerak tanpa dapat dikendalikan (Raini, Dwiprahasto and Sukasediati, 2004).

\section{KESIMPULAN}

Berdasarkan penelitian dan hasil pemeriksaan gambaran kadar enzim cholinesterase pada Wanita Usia Subur (WUS) yang terpapar pestisida di Kecamatan Sukaraja Kabupaten Seluma, dapat disimpulkan bahwa :

Hampir responden seluruh Wanita Usia Subur (WUS) mengalami kadar enzim cholinesterase abnormal dan sebagian kecil responden wanita usia subur dengan kadar enzim normal.

\section{DAFTAR PUSTAKA}

Asror, F., Sulistiyani and Hanani, Y. (2008) 'Faktor Risiko Kejadian Keracunan Pestisida Organofosfat pada Petani Hortikultura di Kecamatan Ngablak Kabupaten Magelang , 2008 Risk Factor of Organophosphate Pesticides Poisoning on Horticultura Sprayer Farmers in agriculture area of Tejosari Village , N', 6(2), pp. 37-40.

Ishii, M. [1] and Kurachi, Y. [1] (2006) 'Muscarinic Acetylcholine Receptors', Current Pharmaceutical Design, 12, pp. 3573-3581. doi: 10.1038/npg.els.0004078.

Ntow, W. J., Tagoe, L. M., Drechsel, P., Kelderman, P., Nyarko, E. and Gijzen, H. J. (2009) 'Occupational exposure to pesticides: Blood cholinesterase activity in a farming community in Ghana', Archives of Environmental Contamination and Toxicology, 56(3), pp. 623-630. doi: 10.1007/s00244-007-9077-2.

Purba, I. G. (2010) 'Analisis Fakto-Faktor Yang Berhubungan Dengan Kadar Kolinesterase Pada Wanita Usia Subur Di Daerah Pertanian', Magister Kesehatan Lingkungan UNDIP.

Raini, M. ., Dwiprahasto, I. . and Sukasediati, N. (2004) 'Pengaruh Istirahat Terhadap Aktivitas Kolinesterase Petani Penyemprot Pestisida Organofosfat di Kecamatan Pacet, Jawa Barat', Buletin Penelitian Kesehatan, 32, pp. 105-111.

Rustia, Bambang, Dewi and Fitra (2010) 'Lama Pajanan Organofosfat Terhadap Penurunan Aktivitas Enzim Cholinesterase Dalam Darah Petani Sayuran', Makara Kesehatan, 14(2), pp. 95-101. 
Yuntari, M. C., Widianarko, B. and Henna Rya Sunoko (2015) 'Jurnal Kesehatan Masyarakat', KEMAS, 10(2), pp. 239245.

Zuraida (2012) 'Universitas indonesia', Faktor yang Berhubungan dengan Tingkat Keracunan Pestisida pada Petani di Desa Srimahi Tambun Utara Beka. 